\title{
The Innovation Trend Research of Retail Business Model in The Internet+ Age

\author{
Jincheng GAO
}

\author{
School of logistics and Trade, Wuhan Business University \\ Wuhan, 430050, China \\ E-mail:gao.sun001@126.com
}

Key word: Internet +, retail business, business model innovation

\begin{abstract}
Facing the great impact brought about by network retail and also the increasing operation cost, traditional retail business model meets with unprecedented challenge. In the Internet + age, big data not only brings choice convenience to consumers but also produces huge impact on traditional consumer behavior, which makes the traditional retail business face the challenge of informationizaion, rapid response to customers' demand, the profitability model, operation cost, and entry and exhibit barrier. Thus, the development trend of retail business model in the Internet + age will mainly innovate in retail operation concept, customer value proposition, critical business process, omni-channel marketing way, retail business subdivision and fusion and so on.
\end{abstract}

\section{Introduction}

With the constant development of Internet economy and mobile information technology, online shopping has exploded in our country in recent years. Online shopping not only produces change on consumer behavior, but also causes huge survival pressure to traditional retail business. Facing tremendous impact brought by network retail and also the increasing operation cost, traditional retail business model meets with unprecedented challenge.

\section{The influence caused by big data on consumer behavior in the Internet+ age}

In the Internet+ age, big data not only brings choice convenience to consumers but also produces huge impact on the traditional consumer behavior. Specifically speaking, this is mainly displayed in the following several aspects:

\section{A. Consumer behavior becomes more mature and rational}

In the past, consumers are unable to obtain accurate and complete information because of information asymmetry between buyers and sellers and also various propaganda sellers easily contributes to passive and blind consumption. In the Internet+ age, it is very easy for consumers to obtain accurate and complete information about products to purchase through network and also mass information brought by big data produces thorough change on information asymmetry between buyers and sellers.[1]Thus, the influence of various propaganda of sellers before consumption is reduced. Through sales information comparison between the retail entity and different online channels, consumers can make more scientific and reasonable consumption decision, making the consumer behavior in the Internet+ age more mature and rational.[2]

\section{B. Individualized consumer behavior is easier to be satisfied}

In the past, standardized commodity and service that the seller provides can hardly meet individualized consumer demand because of single source of information and also the efforts to reduce marketing cost.[3] In the Internet + age, mass information brought by big data makes consumers more imaginative and creative in the consumption and simultaneously individualized demand arises. In this case, sellers have to change standardized commodity and service in the past and provide customized commodity and service through accurate consumer positioning via big data and analysis of demand to satisfy individualized consumer demand better. 


\section{Consumer behavior is more complicated and diverse}

In the past, the limited channel that consumers get information is sometimes influenced by sellers' control and the purchasing process is less influenced by uncertain factor, therefore, it is very easy for sellers to control consumer behavior through investigation and forecast of consumer behavior. In the Internet+ age, mass information brought by big data offers consumers various ways to get information. Various kinds of evaluation information of commodity and service on QQ, microblog, WeChat, forum and so on can easily influence the purchasing decision of consumers and also these open channels of getting information can hardly be influenced by sellers' control, which makes the consumer behavior more complicated and diverse in the Internet+ age.

\section{Brand loyalty of consumers tends to drop}

In the past, since consumers have limited access to brand and can get limited information of similar products of other brands, customers are very likely to have preference for some brand and thus brings lasting and rich profit to some brand as loyal consumers of it. In the Internet + age, mass information brought by big data gives consumers more access to different brands and information of similar products of different brands on QQ, microblog, WeChat and forum comes into consumers' view unceasingly, which leads consumers unconsciously to make repetitive comparison between preference brand and other brands. After comparison, consumers will try new brands and become less loyal to the original brand.

\section{E. Consumer behavior becomes more dependent on network}

In the past, consumers tend to go to retail entity shop to obtain data information of related commodity and service and the traditional consumption concept "seeing is believing" renders the consumer behavior more dependent on retail entity shop. [4] In the Internet + age, mass information brought by big data and the convenience and low cost of online shopping makes consumers less dependent on retail entity shop, and especially, with the development of mobile Internet technology in today's increasing pace of life and work, consumers' fragment time is fully made use of. Rapid and diverse way of payment attracts more and more young consumers to shopping online, making them more dependent on network.

According to the "Marketing research Report of Chinese Online shopping in 2014" issued by China Internet Network Information Center (CNNIC), the online retail market in China maintains rapid growth. In 2014, the online retail turnover is 2.7898 trillion Yuan, increasing by $49.7 \%$. By December, 2014, online shopping users in China achieves 361 million and is 59.53 million more than 2013 and the growth rate is $19.7 \%$; Internet user's proportion of online shopping in China rises from $48.9 \%$ to $55.7 \%$. In terms of the number of online shopping, the total number is 17.3 billion times in 2014 and the transaction per person is 48 times. Meanwhile, the cell phone shopping market in 2014 develops rapidly. In 2014, cell phone online shopping users achieve 236 million and the growth rate is $63.5 \%, 3.2$ times of the growth rate of overall online shopping growth. Phone order increases by $13.5 \%$ to $42.4 \%$.

\section{The challenge facing retail business in the Internet+ age}

In the Internet+ age, traditional retail business model will face the following challenge because of the great influence of big data on traditional consumer behavior.

\section{A. The challenge of informationization}

Traditional retail trade is characteristic of offline experience and offline consumption and the main way that consumers obtain required commodity and service is going window-shopping. However, many consumers are unable to obtain information of required commodity and service because of busy work. [5] Even though these enterprises put emphasis on sales promotion and advertisement to push commodity and service information, the information still get buried in mass information brought by big data due to lack of accurate target customers positioning and demand analysis and nor does the information produce any effect. Thus, traditional retail model in the Internet+ age will face informationization challenge because of low degree of informationization.

\section{$B$. The challenge of rapid response to demand}


In traditional retail business model, traditional retail stores can better satisfy the real shopping demand of consumers, but modern consumers at a quick pace of life and work can hardly experience the convenience and rapidity of online shopping in the Internet+ age. Meanwhile, the logistics and distribution system of traditional business model falls comparatively behind and slow response to commodity distribution and service makes it hard to adapt to rapid response to consumer demand, thus failing to satisfy the individualized demand of consumers.

\section{The challenge of profitability model}

The defects of the general model "channel fee + minimum guarantee deduction point" adopted by traditional retail business are being exposed, which escalates the tension among producers, retailers and consumers to a degree.[6] Meanwhile, for traditional retail model, purchasing cost and storage cost occupy a large proportion in the whole enterprise value chain, which reduces the profit of retail business to a degree and is not good for the long-term development of retail business.

\section{The challenge of operation cost}

Compared with online sale, the operation cost of traditional retail business model is higher. According to the research data on China's top 100 chain enterprises issued by China Chain Operation Association, the shop rent, labor cost and electricity charge of retail enterprises in 2012 increase by $21 \%, 20.5 \%$ and $16 \%$ respectively. Besides the continuously increasing shop rent, labor cost and electricity charge, the employment cost of big management team and high purchasing cost and storage cost also confront many retail enterprises with huge survival pressure under the extrusion of E-business.

\section{E. The challenge of entry and exit barrier}

Retail entity shops are opened in the expansion process of traditional retail business model and the opening and operation of every entity shop requires huge financial support. Meanwhile, shop site, traffic condition and consumption level of this area concerning the retail entity shop have direct effect on the profit of traditional retail enterprises. Once an retail entity shop gets closed due to poor economic benefit, the retail industry will suffer great loss.

\section{The innovation trend of retail business model in the Internet+ age}

In the Internet+ age, the challenge facing traditional retail business model has become the internal innovation drive to innovate it: wide application of big data technology provides powerful technical support for the retail business model innovation. Specifically speaking, the innovation trend of of retail business model in the Internet+ age is mainly displayed in the following aspects.

\section{A. Innovation of retail operation concept}

What traditional retail trade sells is ordinary commodity while what modern retail industry sells is life style with the upgrading of consumption demand. In the Internet + age, consumers can buy required products at lower cost through rapid and convenient online shopping. If it is just about satisfying the demand for certain product, retail entity shop seems to have no meaning for consumers. However, retail entity shop can offer consumers full experience that online shopping couldn't and meanwhile better satisfy consumers' related demand for dinning, relaxation, recreation, making friends and so on. Just because of this, some big department stores are developing toward shopping mall and are changing from previous shopping plaza to today's city life square or super life pavilion.

\section{B. Innovation of customer value proposition}

Consumers' value proposition is profound description of consumers' real demand and also the beginning of business operation. Compared with the analysis of consumer demand from traditional retail business, modern retail business in the Internet+ age can integrate and analyze bulk and various consumer data using big data technology. On the basis of full observation of consumers' demand preference and purchasing behavior, it should know accurately consumers' real demand through accurate search technology to position target customers and designing accurate and timely demand response system to fully satisfy consumers' individualized demand and it should also prompt consumers' individualized value proposition on the basis of ensuring consumers' deep 
participation in enterprise's activities.

\section{The innovation of critical business and process}

In the Internet + age, besides the use of big data to fully observe consumers' demand realization accuracy in the individualized promotion, modern retail business can use big data technology to gather and analyze information from every purchasing experience and also use it to repeatedly optimize the shopping environment, shopping process and service content to make next purchase comply with consumers' preference better and improve the shopping experience level. Meanwhile, modern retail business can also use big data technology to integrate and optimize enterprise's supply chain platform and realize the management innovation of enterprise's supply chain by real-time sharing of critical information in every supply chain node and thus raise the overall efficiency of enterprise operation.

\section{The innovation of subdivision and fusion of retail business}

In the Internet+ age, modern retail department store industry uses big data technology to carry on more precise division of the consumer group on the basis of comprehensive observation of consumer demand and it designs different department store conditions based on different consumer groups to strengthen the pertinence of sales and the stickiness of customers. For example, general department stores can be classified into comprehensive department stores, boutique stores, fashion stores and shopping center according to different consumer groups. Meanwhile, to better satisfy consumer's related living demand for dining, leisure, entertainment and making friends, previous retail stores integrate more modern service element and a fusion of different retail forms appear in some big retail stores. For example, for some big retail stores whose ground floor is supermarket, there still exist various specialty stores in addition to department stores above the ground floor, forming genuine "city life plaza".

\section{Conclusion}

In the Internet+ age, modern retail trade should make full use of accumulated store sales experience. While doing well in retail shop sales, it should also establish its own E-business platform or try to join in the third party E-business platform to develop online sales, such as online store, QQ, microblog, WeChat, forum, mobile Apps and so on to expand online sales and drive retail shop sales by online sales. Retail shop, as the experiencing shop of online sales, should also create real shopping experience for consumers and open the "round-the-clock and all-around" shopping window through establishing online and offline interaction $\mathrm{O} 2 \mathrm{O}$ business model and expand sales of enterprise through omni-channel and thus raise the profit level of enterprise.

\section{Acknowledgment}

In this paper, the research was sponsored by Wuhan Business School's key project “The innovation study of business model of Wuhan department store industry from the perspective of o2o ”in 2015 (Project No. 2015KA005).

\section{References}

[1]Li Fei. Omni-channel marketing theory: three theories to bear the storm of the Chinese multi-channel retail revolution [J]. Beijing Technology and Business University Journal (Social Science Version). 2014(5).

[2]Wang Chengrong. The reform and innovation of department stores under the background of retail revolution [J]. Commercial Economy Studies. 2015(7).

[3] Li Jianqiao. The strategic countermeasures for comprehensive Internet in China [J]. Commercial Economy Studies. 2015(13).

[4]Desyllasa, P., \& Sako, M. Profiting from Business Model Innovation: Evidence from 
Pay-As-You-Drive Auto Insurance [J]. Research Policy, 2013 (1).

[5]Aghekyan-Siraonian M, Forsythe S, Suk Kwon W, et al. The role of product brand image and online store image on perceived risks and online purchase intentions for apparel [J]. Journal of Retailing and Consumer Services, 2012 (3).

[6] Amit R, and Zott C. Creating Value through Business Model Innovation [J].MIT Sloan Management Review. 2012(10). 